\title{
Antioxidant and Organ Protective Potential of the Consciousness Energy Healing-Based Novel Test Formulation Using Different Biomarkers Analysis
}

\author{
Kathryn Regina Sweas ${ }^{1}$, Mahendra Kumar Trivedi ${ }^{1}$, Alice Branton ${ }^{1}$, Dahryn Trivedi ${ }^{1}$, Gopal Nayak ${ }^{1}$, Sambhu Charan \\ Mondal $^{2}$ and Snehasis Jana ${ }^{2 *}$
}

${ }^{1}$ Trivedi Global, Inc., Henderson, Nevada, USA

${ }^{2}$ Trivedi Science Research Laboratory Pvt. Ltd., Thane-West, Maharashtra, India

*Corresponding author: Snehasis Jana, Trivedi Science Research Laboratory Pvt. Ltd., Thane-West, Maharashtra, India

\begin{abstract}
The aim of this paper was to investigate the impact of the Biofield Energy Treatment on the test formulation by focusing on the function of vital organs viz. bones, heart, liver, lungs, and brain in various cell-based assays. The test formulation and the cell media was divided into two parts; one part was untreated (UT) and other part received the Biofield Energy Treatment remotely by a renowned Biofield Energy Healer, Kathryn Regina Sweas, USA and was labeled as the Biofield Energy Treated (BT) test formulation/ media. Cell viability data suggested that the test formulation was safe and non-toxic in nature in six different cells. The experimental group of Biofield Treated medium (BT-Med) + Biofield Treated Test Item (BT-TI) group showed 53.5\%, 127.9\%, and 53.3\% restoration of cell viability, at $0.1,10$, and $25 \mu \mathrm{g} / \mathrm{mL}$, respectively in human cardiac fibroblasts cells (HCF) compared to the UTMed + UT-TI group. Moreover, UT-Med + BT-TI and BT-Med + BT-TI groups showed $42.4 \%$ (at $25 \mu \mathrm{g} / \mathrm{mL}$ ) and $72.6 \%($ at $0.1 \mu \mathrm{g} / \mathrm{mL}$ ), restoration of cell viability, respectively in human hepatoma cells (HepG2) compared to untreated. Furthermore, 67.7\% restoration of cell viability was observed in adenocarcinomic human alveolar basal epithelial cells (A549) by BT-Med + BT-TI group at $0.1 \mu \mathrm{g} /$ $\mathrm{mL}$ compared to the untreated. The alkaline phosphatase (ALP) level was significantly increased by $80.7 \%, 85 \%$, and $93.7 \%$ in the UT-Med + BT-TI, BT-Med + UT-TI, and BT-Med + BT-TI groups, respectively at $10 \mu \mathrm{g} / \mathrm{mL}$ in human bone osteosarcoma cells (MG-63) compared to the untreated. Additionally, the level of ALP was significantly increased by $65.8 \%$ (at $25 \mu \mathrm{g} / \mathrm{mL}$ ) and $106.7 \%$ (at 50 $\mu \mathrm{g} / \mathrm{mL}$ ) in the BT-Med + UT-TI and BT-Med + BT-TI groups, respectively in human endometrial adenocarcinoma cells (Ishikawa) compared to the untreated. The percent protection of HCF (heart) cells (decreased of LDH activity) was significantly increased by $100.9 \%$ (at $0.1 \mu \mathrm{g} / \mathrm{mL}$ ) and $91.2 \%$ (at $10 \mu \mathrm{g} / \mathrm{mL}$ ) in the UT-Med + BT-TI and BT-Med + BT-TI groups, respectively compared to the untreated in HCF cells. The percent protection of HepG2 (liver) cells (decreased of ALT activity) was significantly increased by $51.5 \%$ and $133.6 \%$ at 10 and $63 \mu \mathrm{g} / \mathrm{mL}$, respectively in the BT-Med + BT-TI group compared to untreated in HepG2 cells. The percent protection of A549 (lungs) cells (increased of SOD activity) was significantly increased by $55.8 \%$ (at $10 \mu \mathrm{g} / \mathrm{mL}$ ) and $43.8 \%$ (at $1 \mu \mathrm{g} /$ $\mathrm{mL}$ ) in the UT-Med + BT-TI and BT-Med + UT-TI groups, respectively compared to the untreated in A549 cells. Serotonin level was significantly increased by $80 \%, 77.2 \%$, and $58.7 \%$ in the BT-Med + BT-TI group at 10,25 , and $63 \mu \mathrm{g} / \mathrm{mL}$, respectively as compared to untreated in human neuroblastoma cells (SH-SY5Y). The relative quantification (RQ) of vitamin D receptor (VDR) was significantly increased by 136.8\%, 191.9\%, and 165.8\% in the UT-Med + BT-TI, BT-Med + UT-TI, and BT-Med + BT-TI groups, respectively at 50 $\mu \mathrm{g} / \mathrm{mL}$ compared to the untreated in MG-63 cells. Altogether, results suggest that Biofield Treated test formulation significantly improved the bones, heart, liver, lungs, and brain functional enzyme biomarkers also to protect and maintain the normal function of each vital organs. Therefore, The Trivedi $\mathrm{Effect}^{\circledR} \mathrm{can}$ be used as a complementary and alternative therapy against several disorders such as coronary artery disease, heart attack, congenital heart disease, heart failure, arrhythmias, cirrhosis, cardiomyopathy, liver cancer, Wilson disease, hemochromatosis, pneumonia, chronic bronchitis, asthma, cystic fibrosis, emphysema, osteoporosis, etc.
\end{abstract}

Keywords: The Trivedi Effect ${ }^{\circledR}$; Consciousness Energy Treatment, Bone health; Liver health; Cardiac health; Lungs health; Brain health; VDR receptor 


\section{Introduction}

Bones, heart, liver, lungs, and brain disorders are the major concern of human overall health across the globe. The World Health Organization (WHO) estimates, in 2016, 17.5 million people die due to cardiovascular (heart) disorders, $\sim 3.5$ million people die due to lungs disorders, $\sim 1.3$ million people die due to liver disorders around the globe each year [1]. Moreover, 1.2 million people most frequently diagnosed adult-onset brain disorders in each year in the USA [2]. Three main criteria to keep a healthy heart include the opening blood vessels, strengthening the heart muscle, and controlling free radical damage by antioxidants [3]. The release of liver mitochondrial enzymes is considered strong evidence for hepatic (liver) necrosis, which is associated with an increased production of reactive oxygen species (ROS) that leads to hepatic lipid peroxidation [4-6]. Oxidative stress in the respiratory system increases the production of mediators of pulmonary inflammation and initiate or promote mechanisms of carcinogenesis [7]. The lung is one of the major organs, which is highly exposed by various oxidants i.e., endogenous and exogenous oxidants (cigarette smoke, mineral dust, ozone, and radiation). These oxidants produce free radicals, while reactive oxygen species (ROS) and reactive nitrogen species (RNS) are produced by phagocytes as well as by alveolar, polymorphonuclear, bronchial and different endothelial cells [8]. However, the role of oxidative stress in the pathogenesis of lung diseases has been widely reported such as asthma, chronic obstructive pulmonary disease (COPD), lung malignancies and parenchymal lung diseases like idiopathic pulmonary fibrosis and lung granulomatous diseases [9]. Serotonin (5-hydroxytryptamine, 5-HT) is among the brain's neuromodulators responsible for behavior and understanding [10]. Apart from medicines, nonpharmacologic methods that can increase serotonin by increasing recognition and happiness and well-being. These factors can protect against mental and physical disorders [11]. There is currently no universally accepted test formulation, which improve the organ health biomarkers. With this respect, the novel test formulation was designed on the basis of best scientific literature, which is the combination of herbal products viz. panax ginseng extract and beta carotene, minerals viz. calcium chloride, magnesium gluconate, zinc chloride, sodium selenate, ferrous sulfate, and vitamins viz. vitamin $\mathrm{B}_{12}$, vitamin $\mathrm{D}_{3}$, ascorbic acid, and vitamin $\mathrm{B}_{6}$. This formulation is designed for overall functioning of the organs that can results in improved overall health conditions against many pathological conditions such as lung disorder, liver disorder, breast cancer, liver cancer, aging, muscle damage, and overall health. Minerals and vitamins present in the test formulation provide significant functional support to all the vital organs [12-14]. In addition, panax ginseng is one of the best reported medicinal plants that improve mental, physical abilities, cognitive health, and is potent immunomodulator $[15,16]$.

Various study data suggested the effect of Energy Therapy in cancer patients through therapeutic touch [17], massage therapy [18], etc. Complementary and Alternative Medicine (CAM) therapies are preferred model of treatment, among which Biofield Therapy (or Healing Modalities) is one approach to enhance emotional, mental, physical, and human wellness. The National Center of Complementary and Integrative Health (NCCIH) has recognized and allowed Biofield Energy Healing as a CAM approach in addition to other therapies and medicines such as natural products, chiropractic/osteopathic manipulation, Qi Gong, deep breathing, Tai Chi, yoga, meditation, massage, special diets, healing touch, relaxation techniques, traditional Chinese herbs and medicines, naturopathy, movement therapy, homeopathy, progressive relaxation, guided imagery, pilates, acupuncture, acupressure, Reiki, rolfing structural integration, hypnotherapy, Ayurvedic medicine, mindfulness, essential oils, aromatherapy, and cranial sacral therapy. The Human Biofield Energy has subtle energy that has the capacity to work in an effective manner [19]. CAM therapies have been practiced worldwide with reported clinical benefits in different health disease profiles [20]. This energy can be harnessed and transmitted by the practitioners into living and non-living things via the process of Biofield Energy Healing. The Biofield Energy Treatment, the Trivedi Effect ${ }^{\mathbb{Q}}$, has been reported to have a significant impact in the field of cancer research [21,22], materials science $[23,24]$, microbiology $[25,26]$, agriculture $[27,28]$, nutraceuticals $[29,30]$, and biotechnology [31, 32]. Further, the Trivedi Effect ${ }^{\circledR}$ also significantly improved bioavailability of various low bioavailable compounds [33-35], an improved overall skin health [36,37], bone health [38-40], human health and wellness. Based on the excellent outcomes of the Biofield Energy Therapy in wide spectrum of areas, the authors intend to see the impact of the Biofield Energy Healing Treated test formulation on the function of vital organs such as bones, heart, liver, lungs, and brain specific biomarkers in different cell-lines.

\section{Materials and Methods \\ Chemicals and Reagents}

Ferrous sulfate, vitamin $B_{6}$, vitamin $D_{3}$, vitamin $B_{12}$, calcium chloride, naringenin, trimetazidine (TMZ), 3-(4,5-Dimethylthiazol2-yl)-2,5-Diphenyltetrazolium Bromide (MTT), and ethylenediaminetetraacetic acid (EDTA) were obtained from Sigma Chemical Co. (St. Louis, MO). Zinc chloride, magnesium gluconate, $\beta$-carotene, and calcitriol were purchased from TCI chemicals, Japan. Panax ginseng extract obtained from panacea Phytoextracts, India. Sodium selenate and ascorbic acid were obtained from Alfa Aesar, India. Silymarin and curcumin were obtained from Sanat Chemicals, India and quercetin obtained from Clearsynth, India. Reverse Transcription Kit, RNeasy Mini Kit, and Syber Green PCR kits were procured from Quagen, India. All the other chemicals used in this experiment were analytical grade procured from India.

\section{Biofield Energy Healing Strategy}

The test formulation was the combination of eleven ingredients viz. calcium chloride, panax ginseng extract, vitamin $B_{12}, \beta$-carotene, vitamin $D_{3}$, zinc chloride, magnesium gluconate, sodium selenate, ferrous sulfate, ascorbic acid, and vitamin $B_{6}$. The test formulation and the cell media was divided into two parts; one untreated (UT) and other part received the Biofield Energy Treatment remotely by a renowned Biofield Energy Healer, Kathryn Regina Sweas 
under laboratory conditions for $\sim 3$ minutes through healer's unique Biofield Energy Transmission and was labeled as the Biofield Energy Treated (BT) test formulation/media. Further, the untreated group was treated with a "sham" healer for comparison purposes. The "sham" healer did not have any knowledge about the Biofield Energy Healing Treatment. The Biofield Energy Healer was located in the USA however the test items were located in the research laboratory of Dabur Research Foundation, New Delhi, India. Biofield Energy Healer in this experiment did not visit the laboratory, nor had any contact with the test samples. After that, the Biofield Energy Treated and untreated test items were kept in similar sealed conditions and used for the study as per the study plan.

\section{Assessment of Cell Viability using MTT Assay}

Cells were counted using hemocytometer and plated in 96well plates at the specific density described in (Table 1). The cells were then incubated overnight under growth conditions to allow cell recovery and exponential growth. Following overnight incubation, cells were treated with different concentrations of test formulations (BT/UT). Following respective treatments, cells were incubated in a $\mathrm{CO}_{2}$ incubator at $37^{\circ} \mathrm{C}, 5 \% \mathrm{CO}_{2}$, and $95 \%$ humidity and incubated for time period mentioned in (Table 1). After incubation, the plates were taken out and $20 \mu \mathrm{L}$ of $5 \mathrm{mg} /$ mL of MTT 3-(4,5-dimethylthiazol-2-yl)-2,5-diphenyl tetrazolium bromide solution was added to all the wells followed by additional incubation for 3 hours at $37^{\circ} \mathrm{C}$. The supernatant was aspirated and $150 \mu \mathrm{L}$ of DMSO was added to each well to dissolve formazan crystals. The absorbance of each well was read at $540 \mathrm{~nm}$ using Synergy HT microplate reader. The percentage cytotoxicity at each tested concentration of TI was calculated using Equation 1:

$\%$ Cytotoxicity $=[(\mathrm{R}-\mathrm{X}) / \mathrm{R}] * 100$

Where, $\mathrm{X}=$ Absorbance of treated cells; $\mathrm{R}=$ Absorbance of untreated cells

The concentrations exhibiting percentage cytotoxicity $<30 \%$ were considered as non-cytotoxic [41].

Table 1: Information related to six cell lines with their plating density and time-point.

\begin{tabular}{|c|c|c|c|}
\hline S. No. & Cell Line & Plating & Time Point \\
\hline 1 & MG-63 (Bone) & $3 \times 104$ cells/ well, 96-well plate & 5 days \\
\hline 2 & Ishikawa (Uterus) & $3 \times 104$ cells/ well, 96-well plate & 5 days \\
\hline 3 & A549 (Lung) & $10 \times 104$ cells/ well, 96-well plate & 24 hours \\
\hline 4 & HepG2 (Liver) & $1 \times 104$ cells/ well, 96-well plate & 24 hours \\
\hline 5 & Human Cardiac fibroblasts (Heart) & $1 \times 104$ cells/ well, 96-well plate & 24 hours \\
\hline 6 & SH-SY5Y (Neuronal cell) & $10 \times 104$ cells/ well, 96-well plate & 24 hours \\
\hline
\end{tabular}

\section{Evaluation of the cytoprotective effect of the formulation}

Cells (human cardiac fibroblasts-HCF; human hepatoma cellsHepG2; and adenocarcinomic human alveolar basal epithelial cells-A549) were counted and plated in suitable medium followed by overnight incubation. The cells were then treated with the test items/positive control at the non-cytotoxic concentrations for 24 hours. After 24 hours, oxidative stress was given to the cells using $10 \mathrm{mM} t$-BHP for 3.5 hours. The untreated cells served as a control that did not receive any treatment and was maintained in cell growth medium only. Cells treated with $10 \mathrm{mM}$ of $t$-BHP alone served as negative control. After 3.5 hours of incubation with $t$-BHP the above plates were taken out and cell viability was determined by MTT assay. The percentage protection corresponding to each treatment was calculated using Equation 2:

$\%$ Protection $=\left[\left(\right.\right.$ Absorbance $_{\text {sample }^{-}}-$Absorbance $\left.\left._{\mathrm{t}-\mathrm{BHP}} \mathrm{P}\right)\right] * 100 /$ [Absorbance $_{\text {untreated }}-$ Absorbance $_{\mathrm{t}_{\text {BBHP }}}$ ] ............... (2)

\section{Assessment of alkaline phosphatase (ALP) activity}

The cells (human bone osteosarcoma cells-MG-63 and human endometrial adenocarcinoma cells-Ishikawa) were counted using a hemocytometer and plated in 24-well plates at the density corresponding to $1 \times 10^{4}$ cells/well in phenol-free DMEM supplemented with $10 \%$ CD-FBS. Following the respective treatments, the cells in the above plate were incubated for 48 hours in $\mathrm{CO}_{2}$ incubator at $37^{\circ} \mathrm{C}, 5 \% \mathrm{CO}_{2}$, and $95 \%$ humidity. After 48 hours of incubation, the plates were taken out and processed for the measurement of ALP enzyme activity. The cells were washed with 1 $\mathrm{X}$ PBS and lysed by freeze-thaw method i.e., incubation at $-80^{\circ} \mathrm{C}$ for 20 minutes followed by incubation at $37^{\circ} \mathrm{C}$ for 10 minutes. To the lysed cells, $50 \mu \mathrm{L}$ of substrate solution i.e., $5 \mathrm{mM}$ of $p$-nitrophenyl phosphate ( $p$ NPP) in $1 \mathrm{M}$ diethanolamine and $0.24 \mathrm{mM}$ magnesium chloride $\left(\mathrm{MgCl}_{2}\right)$ solution ( $\left.\mathrm{pH} 10.4\right)$ was added to all the wells followed by incubation for 1 hour at $37^{\circ} \mathrm{C}$. The absorbance of the above solution was read at $405 \mathrm{~nm}$ using Synergy HT microplate reader (Biotek, USA). The absorbance values obtained were normalized with substrate blank ( $p$ NPP solution alone) absorbance values. The percentage increase in ALP enzyme activity with respect to the untreated cells (baseline group) was calculated using Equation 3:

$\%$ Increase in ALP $=\{(\mathrm{X}-\mathrm{R}) / \mathrm{R}\} * 100$

Where, $\quad \mathrm{X}=$ Absorbance of cells corresponding to positive control and test groups

$\mathrm{R}=$ Absorbance of cells corresponding to baseline group (untreated cells)

\section{Estimation of lactate dehydrogenase (LDH) in human cardiac fibroblasts (HCF)}

The human cardiac fibroblasts (HCF) Cells were counted and plated at the density of $0.25 \times 10^{6}$ cells/ well in 24-well plates in cardiac fibroblast specific medium followed by overnight incubation. The cells were then treated with the test formulation/ 
positive control at the non-cytotoxic concentrations for 24 hours. After 24 hours, oxidative stress was given to the cells using $10 \mathrm{mM}$ $t$-BHP for 3.5 hours. The untreated cells were served as control that did not receive any treatment and were maintained in cell growth medium only. Cells treated with $10 \mathrm{mM}$ of $t$-BHP alone served as the negative control. After 3.5 hours of incubation with $t$-BHP the above plates were taken out and LDH activity was determined using LDH activity kit as per manufacturer's instructions. The percent increase in LDH activity was calculated using Equation 4.

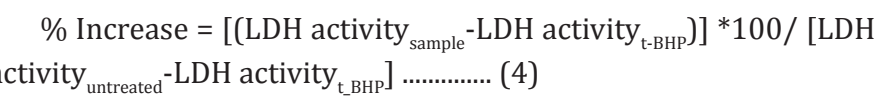

\section{Estimation of ALT in liver cells (HepG2)}

The human hepatoma cells (HepG2) were counted and plated at the density of $5 \times 10^{4}$ cells/well in 48-well plates in DMEM media followed by overnight incubation. The cells were then treated with the test formulation/positive control at the non-cytotoxic concentrations for 24 hours. After 24 hours, oxidative stress was given to the cells using $400 \mu \mathrm{M} t$-BHP for 3.5 hours. The untreated cells served as control that did not receive any treatment and were maintained in cell growth medium only. Cells treated with 400 $\mu \mathrm{M}$ of $t$-BHP alone served as negative control. After 3.5 hours of incubation with $t$-BHP the above plates were taken out and ALT activity was determined using ALT activity kit as per manufacturer's instructions. The percent increase in ALT activity was calculated using Equation 5.

$\%$ Increase $=[($ ALT activity
activity $_{\text {untreated }^{-A L T}}-$ activity
t_BHP $\left._{\text {s. }}\right]$

\section{Estimation of superoxide dismutase (SOD) in lung (A549) cells}

The adenocarcinomic human alveolar basal epithelial cells (A549) were counted and plated at the density of 1 X $10^{4}$ cells/well in 24-well plates in DMEM followed by overnight incubation. The cells were then treated with the test formulation/ positive control at the non-cytotoxic concentrations along with $100 \mu \mathrm{M} t$-BHP to induce oxidative stress. The untreated cells served as control that did not receive any treatment and were maintained in cell growth medium only. Cells treated with $100 \mu \mathrm{M}$ of $t$-BHP alone served as negative control. After 24 hours of incubation with $t$-BHP the above plates were taken out and SOD activity was determined using SOD activity kit as per manufacturer's instructions. The percent increase in SOD activity was calculated using Equation 6:

$\%$ Increase in SOD activity $=((X-R) / R) * 100$

Where, $\mathrm{X}=\mathrm{SOD}$ activity corresponding to Test Item or Positive Control

$\mathrm{R}=\mathrm{SOD}$ activity corresponding to Control group.

\section{Estimation of serotonin in neuronal cells (SH-SY5Y)}

The human neuroblastoma (SH-SY5Y) cells were counted and plated at the density of $10 \times 10^{4}$ cells/well in 96-well plates followed by overnight incubation. The cells were then treated with the test items/positive control at the non-cytotoxic concentrations. The untreated cells served as control that did not receive any treatment and were maintained in cell growth medium only. The treated cells were incubated for 24 hours. Serotonin release was determined by ELISA as per manufacturer's protocol. The percent increase in serotonin levels was calculated using Equation 7.

$[(\mathrm{X}-\mathrm{R}) / \mathrm{R}] * 100$

Where, $\mathrm{X}=$ Serotonin levels corresponding to test item or positive control

$\mathrm{R}=$ Serotonin levels corresponding to control group.

\section{Effect of test formulation on vitamin $D$ receptor (VDR) in bone (MG-63) cells}

The human bone osteosarcoma (MG-63) cells were counted using the hemocytometer were plated at a density of $2 \times 10^{5}$ cells/ well in 6-well plates followed by overnight incubation. The cells were then sera starved for 24 hours and treated with the test formulation/positive control at the non-cytotoxic concentrations. The untreated cells that served as control that did not receive any treatment and were maintained in cell growth medium only. The treated cells were incubated for 24 hours and VDR expression was determined by Q-PCR using VDR specific primers. Cells were harvested by scrapping and washed with PBS. Cell pellets obtained were analyzed for VDR gene expression using human VDR specific primers: Forward: 5'-GCTGACCTGGTCAGTTACAGCA-3', Reverse: 5'-CACGTCACTGACGCGGTACTT-3'. VDR gene expression was normalized using House-keeping (HK) reference. Relative quantification (RQ) of VDR gene in Biofield Energy Treated cells was calculated with respect to the untreated cells using Equation 8:

$\mathrm{RQ}=2-\mathrm{N}$

Where $\mathrm{N}$ is the relative Threshold Cycle (CT) value of treated sample with respect to the untreated sample.

\section{Statistical analysis}

All the values were represented as Mean \pm SD (standard deviation) of three independent experiments. The statistical analysis was performed using Sigma Plot statistical software (v11.0). For two groups comparison student's $t$-test was used. For multiple group comparison, one-way analysis of variance (ANOVA) was used followed by post-hoc analysis by Dunnett's test. Statistically significant values were set at the level of $p \leq 0.05$.

\section{Results and Discussion \\ Cell viability using MTT assay}

Determination of non-cytotoxic concentration of the formulation and positive controls by MTT cell viability assay was used in terms of percent viable cells in six (6) different cell-lines viz. MG-63, Ishikawa, A549, HepG2, HCF, and SH-SY5Y. Based on the percent cell viability data, it was observed that the formulation and positive controls were safe and non-toxic at the tested concentrations in six different cell lines and selected for other parameters analysis.

\section{Evaluation of cytoprotective effect of the test formulation}

The cytoprotective activity of the Biofield Energy Treated test formulation on the restoration of cell viability was determined 
against $t$-BHP induced cell damage and the result is shown in Figure 1. Trimetazidine (TMZ) was used as positive control in human cardiac fibroblasts cells (HCF) and showed, restoration of cell viability by $56.61 \%, 94.09 \%$, and $102.29 \%$ at 5,10 , and $25 \mu \mathrm{g} /$ $\mathrm{mL}$, respectively compared to the $t$-BHP induced group. Besides, the test formulation showed $53.5 \%$ restoration of cell viability at $0.1 \mu \mathrm{g} / \mathrm{mL}$ in the BT-Med + BT-TI group as compared to the UT-Med + UT-TI group. Moreover, at $1 \mu \mathrm{g} / \mathrm{mL}$ the UT-Med + BT-TI and BTMed + UT-TI group showed $34.1 \%$ and $12.9 \%$ restoration of cell viability, respectively than UT-Med + UT-TI group. Additionally, the test formulation showed $23.7 \%$ and $127.9 \%$ restoration of cell viability at $10 \mu \mathrm{g} / \mathrm{mL}$ in the BT-Med + UT-TI and BT-Med + BT-TI groups, respectively as compared to the UT-Med + UT-TI group. Further, at $25 \mu \mathrm{g} / \mathrm{mL}$ the test formulation showed $52.9 \%$ and $53.3 \%$ restoration of cell viability, respectively in the BT-Med + UT-TI and BT-Med + BT-TI groups, respectively than UT-Med + UTTI group. Further, the test formulation showed $33.1 \%$ and $35.1 \%$ restoration of cell viability at $63 \mu \mathrm{g} / \mathrm{mL}$ in the UT-Med + BT-TI and BT-Med + BT-TI groups, respectively as compared to the UT-Med + UT-TI group (Figure 1). Silymarin was used as positive control in human hepatoma cells (HepG2) resulted, restoration of cell viability by $38.4 \%, 56.6 \%$, and $72.6 \%$ at 5,10 and $25 \mu \mathrm{g} / \mathrm{mL}$, respectively compared to the $t$-BHP induced group. Besides, the test formulation showed $42.4 \%$ (at $25 \mu \mathrm{g} / \mathrm{mL}$ ), 23.0\% (at $10 \mu \mathrm{g} / \mathrm{mL}$ ), and $72.6 \%$ (at $0.1 \mu \mathrm{g} / \mathrm{mL}$ ) restoration of cell viability in the UT-Med + BT-TI, BTMed + UT-TI, and BT-Med + BT-TI groups, respectively as compared to the UT-Med + UT-TI group (Figure 1). Quercetin was used as positive control in adenocarcinomic human alveolar basal epithelial cells (A549) resulted, restoration of cell viability by $65.7 \%, 76.7 \%$, and $86.1 \%$ at 5,10 and $25 \mu \mathrm{g} / \mathrm{mL}$, respectively compared to the $t$-BHP induced group. Besides, the test formulation showed $28.2 \%$ and $67.7 \%$ restoration of cell viability at $0.1 \mu \mathrm{g} / \mathrm{mL}$ in the BT-Med + UT-TI and BT-Med + BT-TI groups, respectively compared to the UT-Med + UT-TI group (Figure 1). Tert-butyl hydroperoxide ( $t$-BHP) has been extensively utilized as an oxidative stress marker in various cells [41]. In this study, $t$-BHP was used an oxidative stress inducer for the assessment of various vital organs viz. heart, liver, and lungs using cell-based assay. Thus, restoration of cell viability from t-BHP induced oxidative stress by Biofield Energy Treated novel proprietary test formulation could be due to the either upregulated the expression of heme oxygenase 1 (HO-1) and NAD(P) $\mathrm{H}$ quinone oxidoreductase 1 (NQO1) or induction of antioxidantresponsive-element (ARE)-dependent luciferase activation, nuclear factor (erythroid-derived 2)-like 2 (Nrf2) nuclear translocation, and mitogen-activated-protein-kinase (MAPK) phosphorylation [42]. The study results suggest that Biofield Energy Treatment has significantly protects $t$-BHP induced cardiotoxicity, hepatotoxicity, and lung cell toxicity which could be due to The Trivedi Effect ${ }^{\mathbb{B}}$ Biofield Energy Healing. Therefore, Biofield Energy Healing Treatment could be used for the management of cardiovascular, liver, and various lung disorders.

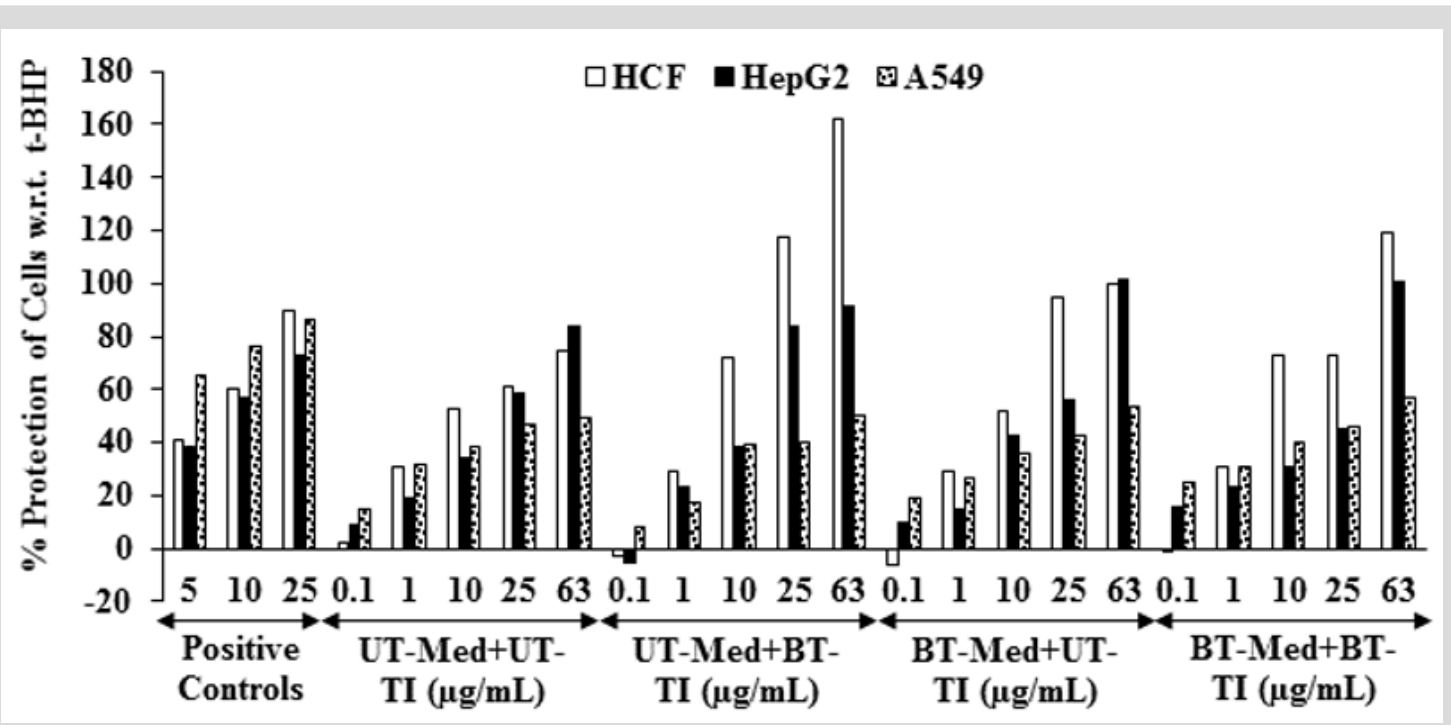

Figure 1: Assessment of cytoprotective effect of the test formulation in human cardiac fibroblasts cells (HCF), human hepatoma cells (HepG2), and adenocarcinomic human alveolar basal epithelial cells (A549) against tert-butyl hydroperoxide ( $t$-BHP) induced damage. TMZ: Trimetazidine $(\mu \mathrm{M})$, silymarin $(\mu \mathrm{g} / \mathrm{mL})$, and quercetin $(\mu \mathrm{M})$ were used as positive control in HCF, HepG2, and A549 cells, respectively. UT: Untreated; Med: Medium; BT: Biofield Treated; TI: Test item.

\section{Assessment of Alkaline Phosphatase (ALP) Activity}

The effect of the test formulation on bone-specific alkaline phosphatase level is shown in Figure 2. The positive control, calcitriol showed $13.19 \%, 21.41 \%$, and $35.37 \%$ increased the level of ALP at $0.1,1$, and $10 \mathrm{nM}$, respectively in MG-63 cells. Moreover, the experimental groups showed $80.7 \%, 85 \%$, and $93.7 \%$ increased the level of ALP in the UT-Med + BT-TI, BT-Med + UT-TI, and BT-
Med + BT-TI groups, respectively with respect to the UT-Med + UT-TI group at $10 \mu \mathrm{g} / \mathrm{mL}$. At $50 \mu \mathrm{g} / \mathrm{mL}$, the percent ALP was significantly increased by $85.5 \%, 87.7 \%$, and $81.5 \%$ in the UT-Med + BT-TI, BTMed + UT-TI, and BT-Med + BT-TI groups, respectively compared to the UT-Med + UT-TI group (Figure 2). Besides, the positive control naringenin showed $35.18 \%, 77.51 \%$, and $130.24 \%$ increased the level of ALP at 2.5, 5, and $10 \mathrm{nM}$, respectively in Ishikawa cells. 
ALP percent was significantly increased by $55.5 \%$ and $65.8 \%$ in the UT-Med + BT-TI and BT-Med + UT-TI groups, respectively as compared to the UT-Med + UT-TI group at $25 \mu \mathrm{g} / \mathrm{mL}$. Moreover, the experimental groups showed $66.2 \%, 41.8 \%$, and $106.7 \%$ increased the level of ALP in the UT-Med + BT-TI, BT-Med + UT-TI, and BTMed + BT-TI groups, respectively with respect to the UT-Med + UT-TI group at $50 \mu \mathrm{g} / \mathrm{mL}$ (Figure 2). Bone-specific alkaline phosphatase (BAP) is synthesized by the osteoblast cells and is it responsible for the calcification of bone matrix. ALP is normally considered as a laboratory tool in the panel of bone and liver function tests [43].
In the case of osteoporosis the ALP activity rate is normal; while it has been increased by 2 to 4 times in case of rickets and slowly decreased by vitamin D therapy. Another literature also reported that a very high levels of ALP enzyme activity is also observed in patients with bone metastatic carcinoma and osteogenic sarcoma [44]. Here, the level of ALP was exhibited that the Biofield Energy Healing Treated novel proprietary test formulation has significantly increased the level of ALP expression, which might be very helpful to the patients suffering from various bone-related disorders.
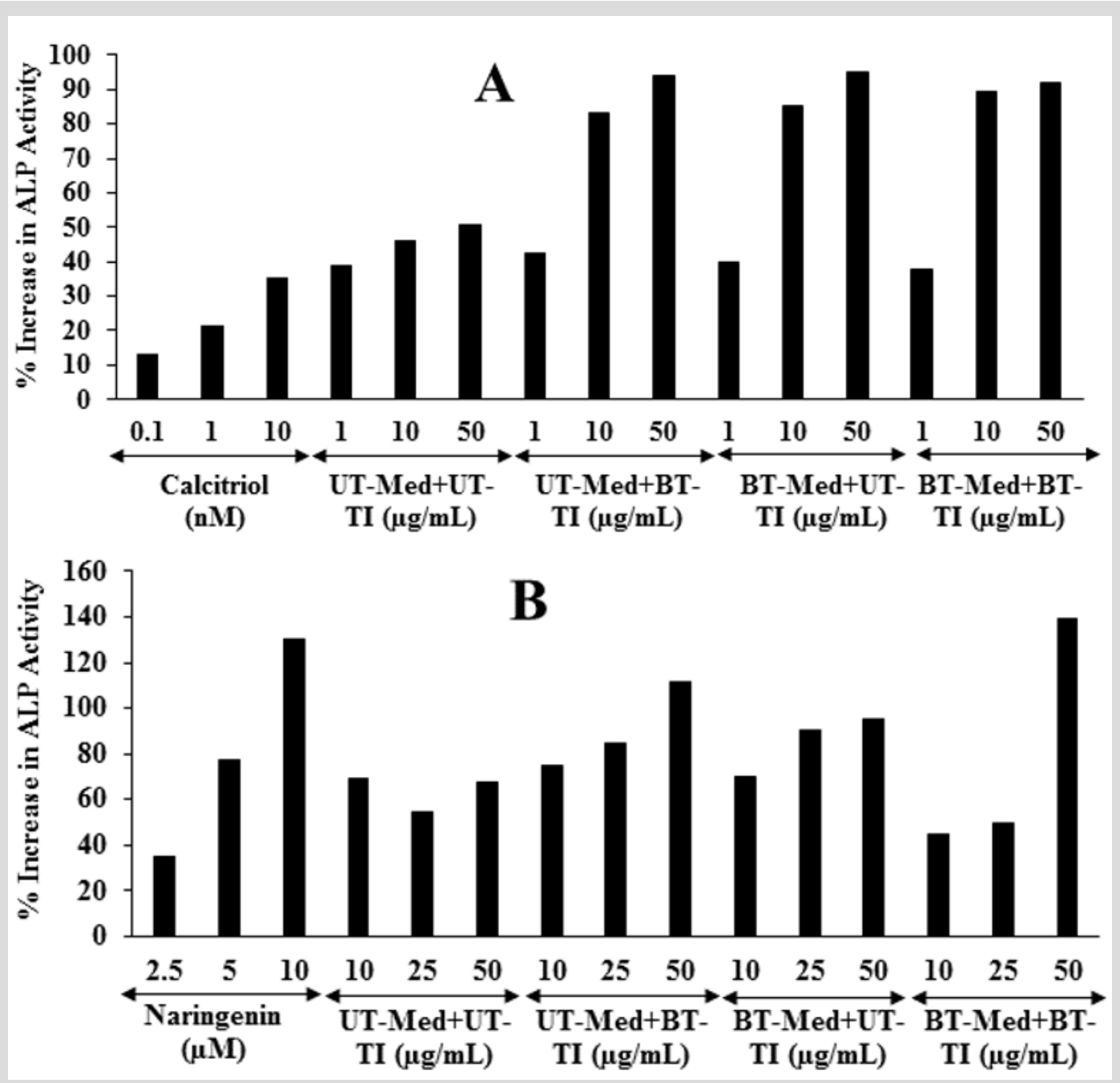

Figure 2: The effect of the test formulation on alkaline phosphatase (ALP) in A. Human bone osteosarcoma cells (MG-63) and B. Human endometrial adenocarcinoma cells (Ishikawa). Calcitriol and naringenin were used as positive control in Mg-63 and Ishikawa cells, respectively. UT: Untreated; Med: Medium; BT: Biofield Treated; TI: Test item.

Estimation of lactate dehydrogenase (LDH) activity in human cardiac fibroblasts (HCF)

The effect of test formulation on the percent protection of HCF cells in terms of decreased level of lactate dehydrogenase (LDH) activity is shown in (Figure 3). The positive control, trimetazidine (TMZ) exhibited $3.59 \%, 30.14 \%$, and $69.42 \%$ protection of HCF cells (decreased of LDH activity) compared to the $t$-BHP group. The percent protection of HCF cells (decreased of LDH activity) was significantly increased by $100.9 \%$ and $87.7 \%$ at $0.1 \mu \mathrm{g} / \mathrm{mL}$ in the UT-Med + BT-TI and BT-Med + UT-TI groups, respectively as compared to the UT-Med + UT-TI group. Moreover, at $1 \mu \mathrm{g} / \mathrm{mL}$, the percent protection of HCF cells (decreased of LDH activity) was significantly increased by $83.7 \%, 28.4 \%$, and $56.5 \%$ in the UT-Med + BT-TI, BT-Med + UT-TI, and BT-Med + BT-TI groups, respectively as compared to the UT-Med + UT-TI group. Further, percent protection of HCF cells (decreased of LDH activity) was also significantly increased by $74.6 \%$ and $91.2 \%$ in the UT-Med + BT-TI and BT-Med + BT-TI groups, respectively at $10 \mu \mathrm{g} / \mathrm{mL}$ as compared to the UTMed + UT-TI group (Figure 3). LDH is a pathologic biomarker for a wide variety of cardiovascular disorders (CVDs) such as myocardial 
ischemia, strenuous, etc. Various heavy metals exposure can increased the level of LDH and simultaneously more prone to CVDs [45]. The levels of LDH become high in case of cardiovascular (CBDs), hepatic (liver), and pulmonary (lungs) patients [46,47]. The study results found that there was a significant reduction of LDH level after Biofield Energy Treatment and protect heart cells, which might be helpful to resist against various pathological conditions like tissue injury, necrosis, hemolysis or malignancies, hypoxia, etc. It also indicating that the heart cells acted normally under stress and anaerobic condition and improved overall heart function.

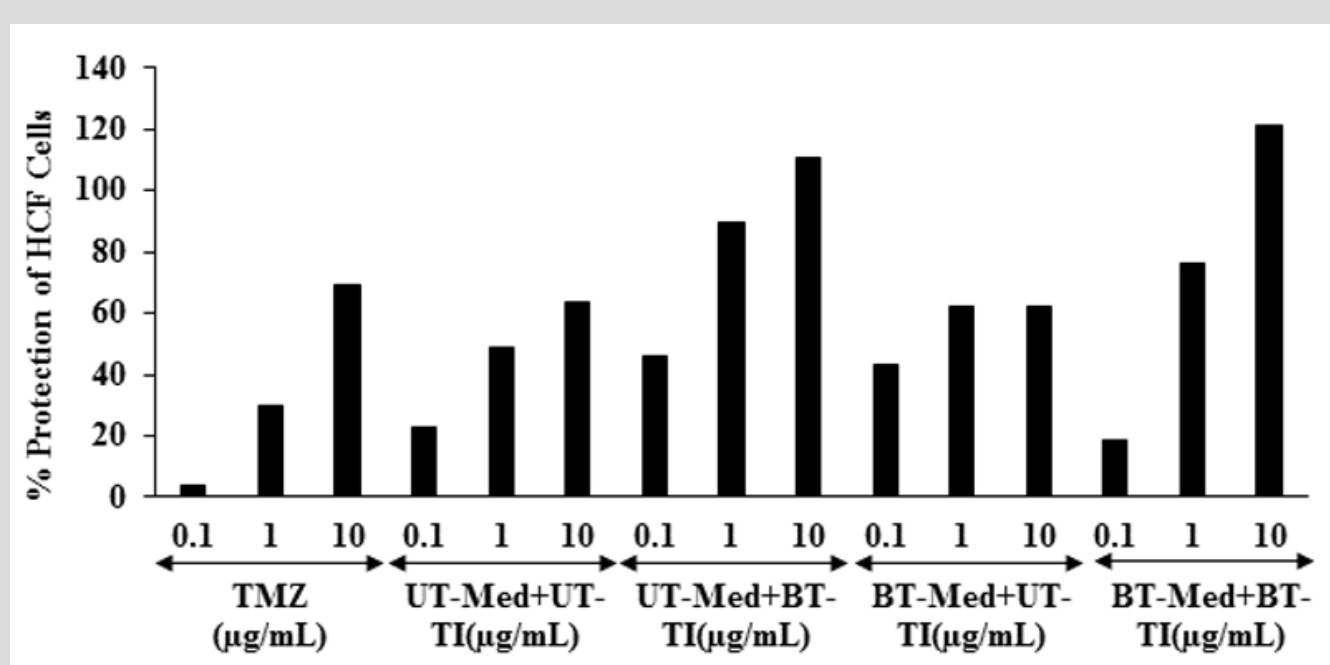

Figure 3: The effect of the test formulation on the percent protection of HCF cells in terms of decreased lactate dehydrogenase (LDH) activity against tert-butyl hydroperoxide ( $t$-BHP) induced damage. TMZ: Trimetazidine; UT: Untreated; Med: Medium; BT: Biofield Treated; TI: Test item.

\section{Estimation of alanine amino transferase (ALT) activity in HepG2 cells}

The effect of the test formulation on protection of HepG2 cells in terms of decrease alanine amino transferase (ALT) activity is shown in (Figure 4). The positive control, silymarin showed $6.56 \%$, $74.51 \%$, and $106.27 \%$ protection of HepG2 cells (decreased of ALT activity). The protection of HepG2 cells (decreased of ALT activity) was significantly increased by $8.2 \%, 27.6 \%$, and $51.1 \%$ at $10 \mu \mathrm{g} / \mathrm{mL}$ in the UT-Med + BT-TI, BT-Med + UT-TI, and BT-Med + BT-TI groups, respectively as compared to the UT-Med + UT-TI group. Moreover, at $25 \mu \mathrm{g} / \mathrm{mL}$, percent protection of HepG2 cells (decreased of ALT activity) was increased by $38.6 \%$ and $38.9 \%$ in the BT-Med + UT-TI and BT-Med + BT-TI groups, respectively as compared to the UT-
Med + UT-TI group. Further, protection of HepG2 cells (decreased of ALT activity) was also significantly increased by $39.6 \%, 22.8 \%$, and $133.6 \%$ in the UT-Med + BT-TI, BT-Med + UT-TI, and BT-Med + BT-TI groups, respectively at $63 \mu \mathrm{g} / \mathrm{mL}$ as compared to the UTMed + UT-TI group (Figure 4). ALT is an excellent biomarker of hepatocellular injury. ALT catalyze the transfer of amino groups from alanine to ketoglutaric acid to produce oxaloacetic acid [48]. Activity of alanine aminotransferase (ALT) as an indicator of health and disease. Its activity not only measured to detect liver disease, but also to monitor overall health [49,50]. Here, the Biofield Energy Treatment significantly protect liver hepatocytes in terms of reducing the level of transaminases enzyme, ALT compared to the $t$-BHP inducing group, which might be due to Consciousness Energy Healing Treatment to the test formulation.

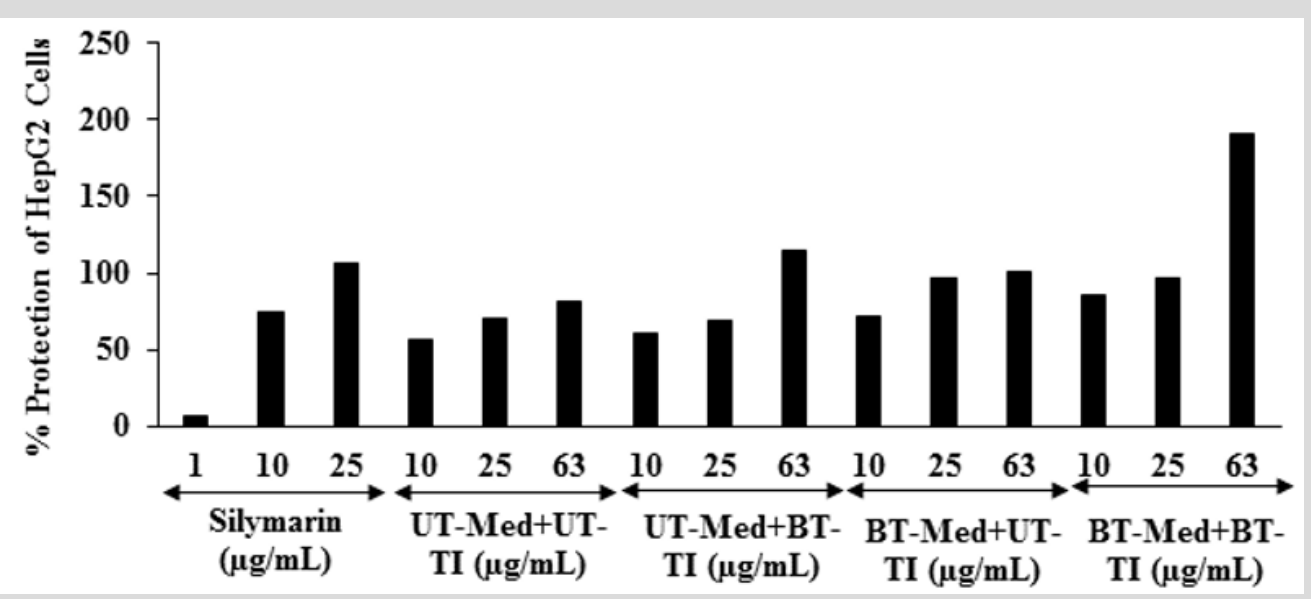

Figure 4: Effect of the test formulation on the percent protection of human liver cancer (HepG2) cells in terms of decreased alanine amino transaminase (ALT) activity under the stimulation of tert-butyl hydroperoxide ( $t$-BHP). UT: Untreated; Med: Medium; BT: Biofield Treated; TI: Test item 
Estimation of superoxide dismutase (SOD) activity in adenocarcinomic human alveolar basal epithelial cells (A549)

The effect of the test formulation on the protection of lungs cells (A549) in terms of increased super oxide dismutase (SOD) activity is shown in Figure 5. The positive control, showed 62.09\%, $80.28 \%$, and $93.87 \%$ protection of A549 (lungs) cells (increased of SOD activity) compared to the $t$-BHP group. The percent protection of A549 (lungs) cells (increased of SOD activity) was significantly increased by $8.6 \%$ and $43.8 \%$ at $1 \mu \mathrm{g} / \mathrm{mL}$ in the UT-Med + BT-TI and BT-Med + UT-TI groups, respectively compared to the UT-Med + UT-TI group. Moreover, at $10 \mu \mathrm{g} / \mathrm{mL}$, the percent protection of A549 (lungs) cells (increased of SOD activity) was significantly increased by $55.8 \%, 42.2 \%$, and $22.3 \%$ in the UT-Med + BT-TI, BT-Med + UT-TI, and BT-Med + BT-TI groups, respectively as compared to the UTMed + UT-TI group (Figure 5). Oxidative stress is a crucial causative factor for lung disorder like chronic obstructive pulmonary disease (COPD). Superoxide dismutases (SODs) can prevent an increase in oxidative burden by converting the superoxide radicals to hydrogen peroxide [51,52]. Altogether, data observed that a significant increased SOD level after Biofield Energy Treatment in A549 cells, which might be helpful to resist against various pathological conditions like oxidative stress and related adverse effect. It also indicating that the lung cells acted normally and improved overall respiratory activities.

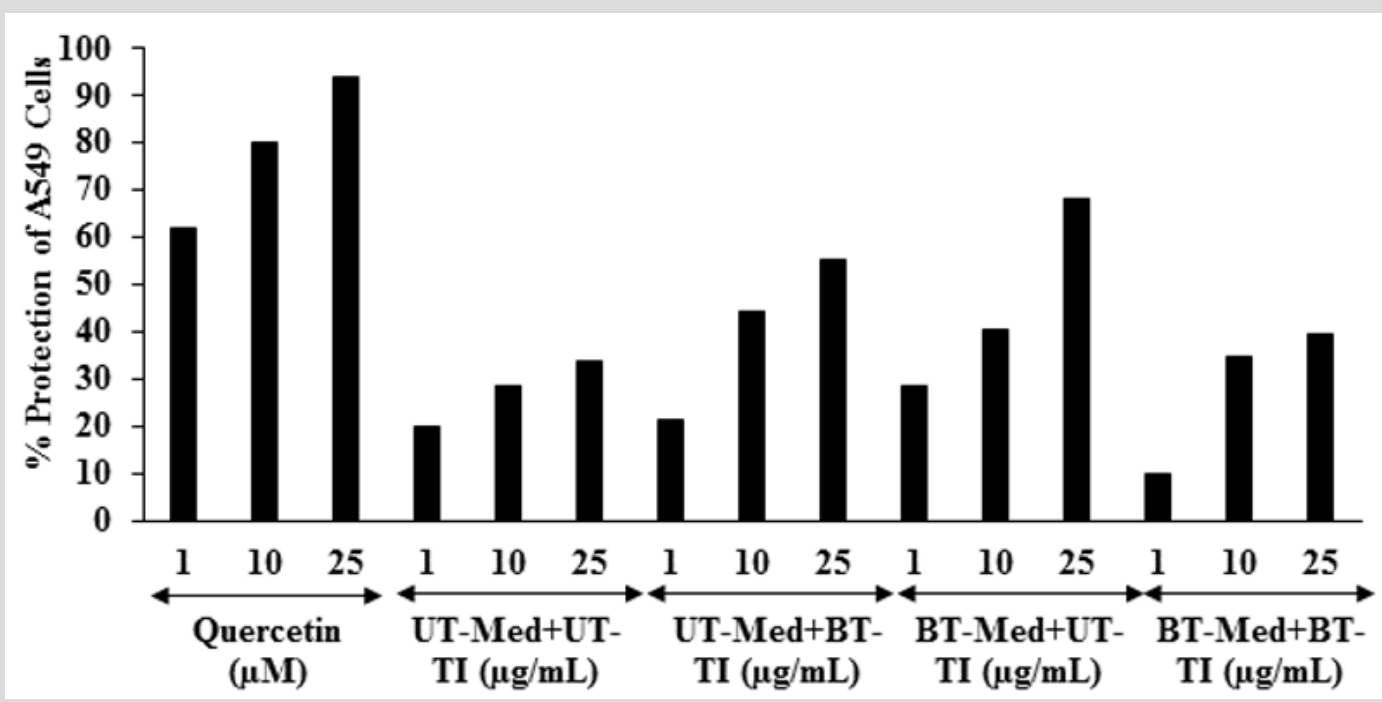

Figure 5: Effect of the test formulation on the percent protection of lungs cells (A549) in terms of increased SOD activity under the stimulation of tert-butyl hydroperoxide ( $t$-BHP). UT: Untreated; Med: Medium; BT: Biofield Treated; TI: Test item.

\section{Effect of test formulation on serotonin in human neuroblastoma (SH-SY5Y) cells}

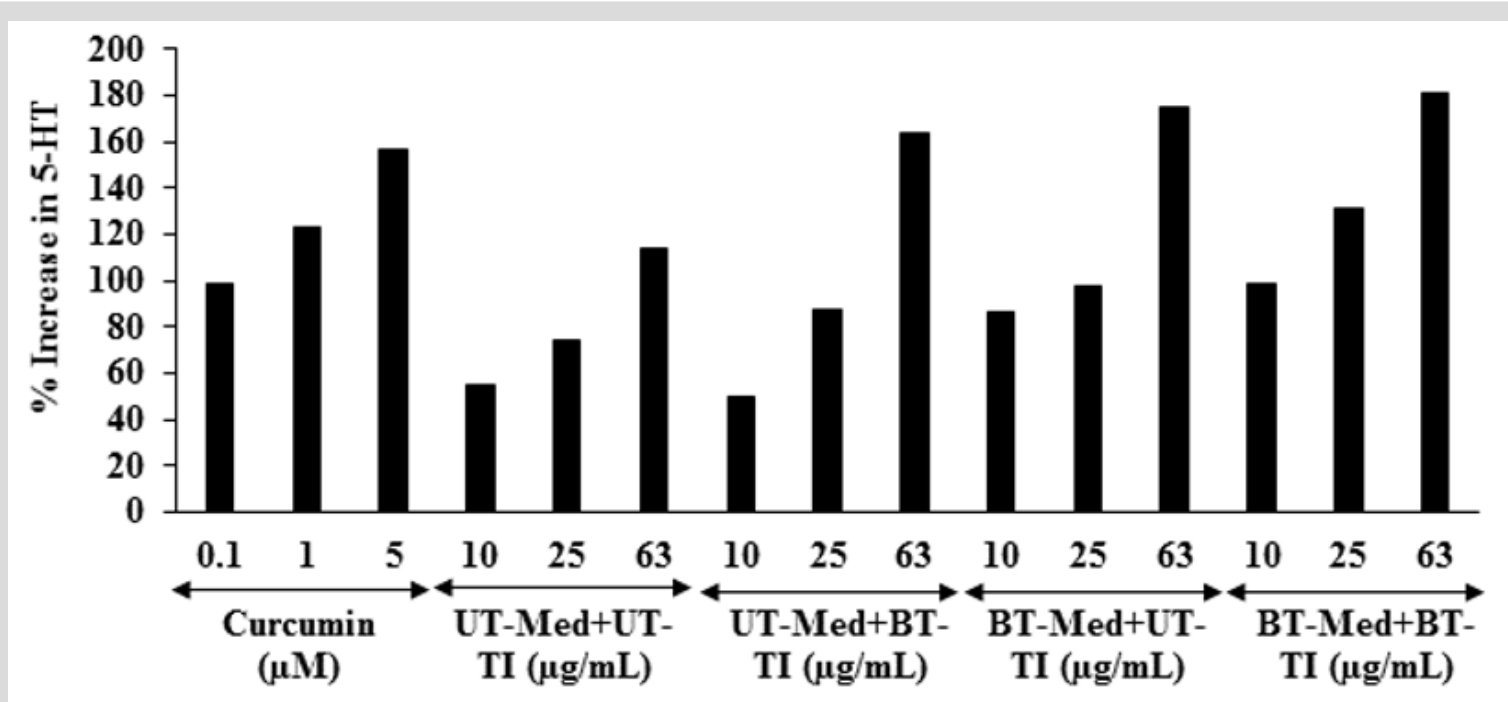

Figure 6: Effect of the test formulation on percent increase in 5-hydroxy tryptamine (5-HT) or serotonin in human neuroblastoma cells (SH-SY5Y). UT: Untreated; Med: Medium; BT: Biofield Treated; TI: Test item. 
The effect of test formulation on the level of serotonin in SHSY5Y cells is shown in Figure 6. The positive control, showed $98.2 \%, 123.53 \%$, and $156.76 \%$ increased the level of serotonin. The level of serotonin was significantly increased by $58 \%$ and $80 \%$ in the BT-Med + UT-TI and BT-Med + BT-TI groups, respectively at $10 \mu \mathrm{g} / \mathrm{mL}$ compared to the UT-Med + UT-TI group. Moreover, at 25 $\mu \mathrm{g} / \mathrm{mL}, 5$-HT level was significantly increased by $17.6 \%, 31.7 \%$, and $77.2 \%$ in the UT-Med + BT-TI, BT-Med + UT-TI, and BT-Med + BT-TI groups, respectively as compared to the UT-Med + UT-TI group. Further, the serotonin level was significantly increased by $43.3 \%, 53.2 \%$, and $58.7 \%$ in the UT-Med + BT-TI, BT-Med + UT-TI, and BT-Med + BT-TI groups, respectively at $63 \mu \mathrm{g} / \mathrm{mL}$ as compared to the UT-Med + UT-TI group (Figure 6). Serotonin (5HT) is a neurotransmitter responsible for stress, anxiety, aggressive behavior, and for the regulation of blood pressure Loss of 5-HT leads to various neuropsychiatric disorders such as depression, memory loss, Alzheimer's disease, cognitive health, loss of ability of thinking, etc. Several studies have been reported that mood change directly link with the level of serotonin. For example, lower mood is due to lower platelet serotonin ${ }_{2}$ receptor function or lower level of serotonin; whereas better mood is associated with higher blood serotonin levels [53,54]. Apart from brain tissue serotonin can impact on hematopoietic system, immune responses, and tissue regeneration support utilization of serotonin as a potential therapeutic target for the treatment of hematological diseases and organ repair [55]. Here, in this study, the Biofield Energy Treated novel test formulation and Biofield Energy Treatment per se have significantly increased the level of serotonin, which might beneficial for various neurodegenerative diseases and other age-related disorders and improved the normal functioning of the brain tissues i.e., brain health.

\section{Effect of test formulation on vitamin D receptors (VDRs)}

The effect of the test formulation on VDR expression was determined using quantitative-polymerase chain reaction (Q-PCR) amplification in human bone osteosarcoma cells (MG-63). VDRrelative threshold cycle (VDR-CT) values were obtained from PCR amplification. Relative quantification (RQ) was calculated from the VDR-CT and house-keeping (HK)-CT values for MG-63 cells treated with test formulation and positive control is shown in Figure 7. The positive control (calcitriol) showed 65.86\%, 109.94\%, and $154.91 \%$ increase of RQ of VDR at 1, 10, and $100 \mathrm{nM}$, respectively. Moreover, RQ of VDR was significantly increased by $22.1 \%, 61 \%$, and $95.6 \%$ in the UT-Med + BT-TI, BT-Med + UT-TI, and BT-Med + BT-TI groups, respectively at $1 \mu \mathrm{g} / \mathrm{mL}$ compared to the UT-Med + UT-TI group. Additionally, at $10 \mu \mathrm{g} / \mathrm{mL}$ the VDR level was significantly increased by $15.5 \%, 134.6 \%$, and $115.7 \%$ in the UT-Med + BT-TI, BT-Med + UT-TI, and BT-Med + BT-TI groups, respectively as compared to the UT-Med + UT-TI group. Further, VDR level was also significantly increased by $136.8 \%, 191.9 \%$, and $165.8 \%$ in the UT-Med + BT-TI, BT-Med + UT-TI, and BT-Med + BT-TI groups, respectively at $50 \mu \mathrm{g} /$ $\mathrm{mL}$ compared to the UT-Med + UT-TI group. VDRs are found in all types of the skeleton such as osteocytes, chondrocytes, osteoclasts, and osteoblasts. Deficiency of vitamin D is due to lack of functional VDRs, which can be reverse using diets containing more calcium and phosphate [56,57]. Here, in this experiment the Biofield Energy treated test formulation has significantly increased the expression of VDRs, which might be helpful to maintain adequate vitamin D level for the normal growth and development of bone cells.

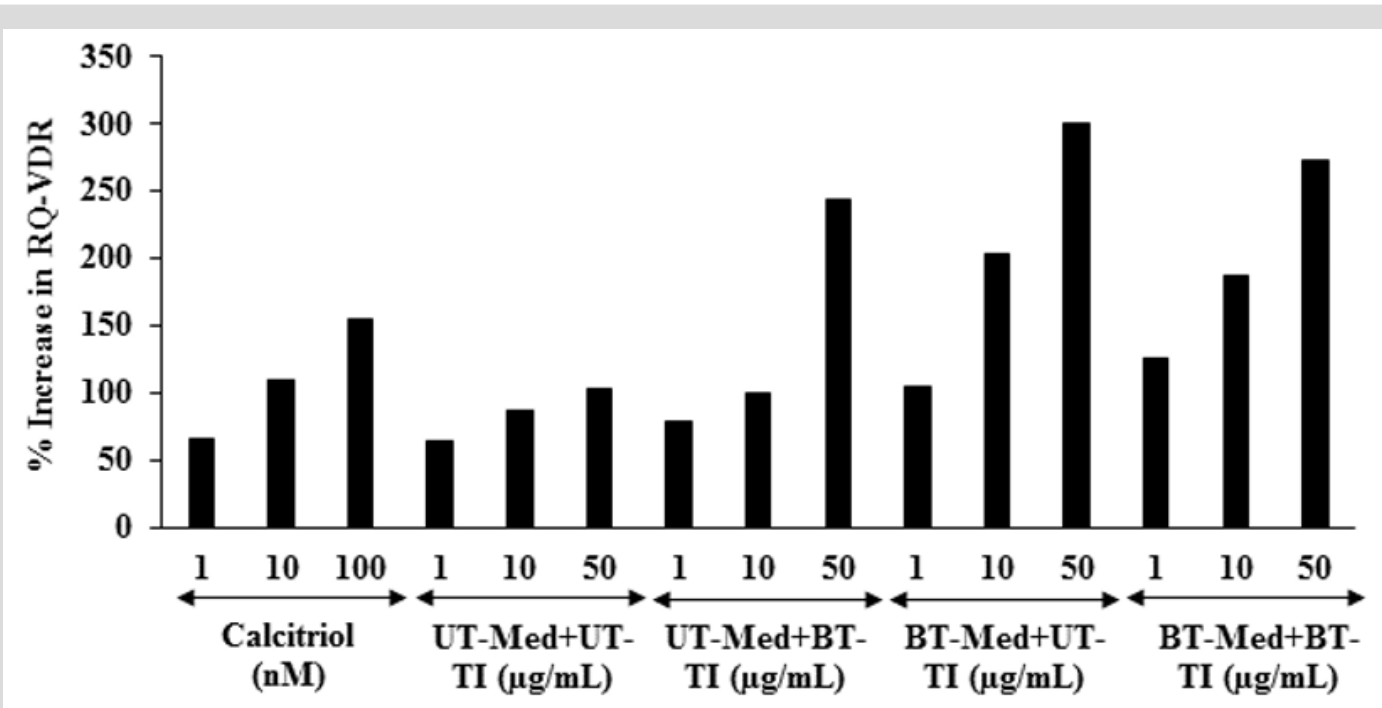

Figure 7: Effect of the test formulation on percent increase in relative quantification (RQ) of vitamin D receptors (VDRs) gene in human bone osteosarcoma cells (MG-63). UT: Untreated; Med: Medium; BT: Biofield Treated; TI: Test item.

\section{Conclusion}

The study findings showed that the tested novel test formulation was safe and non-toxic based on MTT cell viability assay in six tested cells. The BT-Med + BT-TI group showed 53.5\%, 127.9\%, and $53.3 \%$ restoration of cell viability at $0.1,10$, and $25 \mu \mathrm{g} / \mathrm{mL}$, respectively in human cardiac fibroblasts cells (HCF) compared to the UT-Med + UT-TI group. Moreover, the BT-Med + BT-TI group showed $72.6 \%$ and $67.7 \%$ restoration of cell viability at $0.1 \mu \mathrm{g} / \mathrm{mL}$ in human hepatoma cells (HepG2) and adenocarcinomic human alveolar basal epithelial cells (A549), respectively compared to the untreated group. Alkaline phosphatase (ALP) activity was 
significantly increased by $80.7 \%$, $85 \%$, and $93.7 \%$ in the UT-Med + BT-TI, BT-Med + UT-TI, and BT-Med + BT-TI group at $10 \mu \mathrm{g} / \mathrm{mL}$ in human bone osteosarcoma cells (MG-63). Moreover, ALP activity was significantly increased by $106.7 \%$ in the BT-Med + BT-TI group at $50 \mu \mathrm{g} / \mathrm{mL}$ than untreated group. The percent protection of HCF cells (decreased of LDH activity) was significantly increased by $100.9 \%$ (at $0.1 \mu \mathrm{g} / \mathrm{mL}$ ) and $91.2 \%$ (at $10 \mu \mathrm{g} / \mathrm{mL}$ ) in the UT-Med + BT-TI and BT-Med + BT-TI groups, respectively compared to the untreated group in HCF cells. The percent protection of HepG2 cells (decreased of ALT activity) was significantly increased by $133.6 \%$ at $63 \mu \mathrm{g} / \mathrm{mL}$ in the BT-Med + BT-TI group compared to the untreated group in HepG2 cells. The percent protection of A549 (lungs) cells (increased of SOD activity) was significantly increased by $55.8 \%$ in the UT-Med + BT-TI group at $10 \mu \mathrm{g} / \mathrm{mL}$ compared to the untreated group in A549 cells. The serotonin level was significantly increased by $80 \%, 77.2 \%$, and $58.7 \%$ in the BT-Med + BT-TI group at 10,25 , and $63 \mu \mathrm{g} / \mathrm{mL}$, respectively compared to the untreated group in human neuroblastoma cells (SH-SY5Y). The relative quantification (RQ) of vitamin D receptors (VDRs) level was significantly increased by $136.8 \%, 191.9 \%$, and $165.8 \%$ in the UT-Med + BT-TI, BT-Med + UT-TI, and BT-Med + BT-TI groups, respectively compared to the untreated group in MG-63 cells. In conclusion, The Biofield Energy Treatment significantly improved heart, liver, bones, neuronal, and lungs related functional enzyme biomarkers and also protected cardiomyocyte, hepatocyte, osteocytes, pneumocyte, and nerve cells from oxidative damage induced by tert-butyl hydroperoxide ( $t$-BHP). Thus, results suggested that Biofield Energy Treatment can be used as a complementary and alternative treatment for the prevention of various types of cardiac disorders (peripheral artery disease, high blood pressure, congenital heart disease, stroke, congestive heart failure, rheumatic heart disease, carditis, valvular heart disease, thromboembolic disease, and venous thrombosis, etc.), hepatic disorders (cirrhosis, Wilson disease, liver cancer, hemochromatosis), and lungs disorders (Asthma, Emphysema, Chronic bronchitis, Pneumonia, Cystic fibrosis). Further, it can be useful to improve cell-to-cell messaging, normal cell growth and differentiation, cell cycling and proliferation, neurotransmission, skin health, hormonal balance, immune and cardiovascular functions. Moreover, it can also be utilized in organ transplants (i.e., liver, kidney, and heart transplants), aging, hormonal imbalance and various inflammatory and immune-related disease conditions like Alzheimer's Disease (AD), Dermatitis, Asthma, Ulcerative Colitis (UC), Hashimoto Thyroiditis, Pernicious Anemia, Sjogren Syndrome, Aplastic Anemia, Multiple Sclerosis, Hepatitis, Graves' Disease, Irritable Bowel Syndrome (IBS), Dermatomyositis, Diabetes, Myasthenia Gravis, Atherosclerosis, Parkinson's Disease, Systemic etc. to Lupus Erythematosus (SLE), stress, improve overall health and Quality of Life.

\section{Acknowledgement}

Authors gratefully acknowledged to Trivedi Global, Inc., Trivedi Science, and Trivedi Master Wellness for their support. In addition, authors are thankful for the support of Dabur Research Foundation for conducting this study.

\section{References}

1. (2017) Global Burden of Disease Collaborative Network. Global Burden of Disease Study 2016 (GBD 2016) Results. Seattle, Institute for Health Metrics and Evaluation (IHME), United States.

2. Pal S (2018) Incidence and prevalence of major neurologic disorders. US Pharm 43(1): 24.

3. Rakesh S, Arunporn I (2017) Herbal supplements or herbs in heart disease: Herbiceutical formulation, clinical trials, futuristic developments. J Cardiol Cardiovasc Ther 3(1): 555603.

4. Contreras-Zentella ML, Hernández-Muñoz R (2016) Is liver enzyme release really associated with cell necrosis induced by oxidant stress? Oxid Med Cell Longev 2016: 3529149.

5. Schmidt E, Schmidt FW (1970) Aspects of enzyme diagnosis. Med Welt 21: 805-816.

6. Frederiks WM, Vogels IM, Fronik GM (1984) Plasma ornithine carbamyl transferase level as an indicator of ischaemic injury of rat liver. Cell Biochem Funct 2: 217-220.

7. Boots AW, Haenen GR, Bast A (2003) Oxidant metabolism in chronic obstructive pulmonary disease. Eur Respir J 46: 14S-27S.

8. Romieu I (2005) Nutrition and lung health. Int J Tuberc Lung Dis 9: 362374.

9. Kelly FJ (2005) Vitamins and respiratory disease: Antioxidant micronutrients in pulmonary health and disease. Proc Nutr Soc 64: 510526.

10. Fischer AG, Ullsperger M (2017) An update on the role of serotonin and its interplay with dopamine for reward. Front Hum Neurosci 11: 484.

11. Anonymous (2006) A sensible 10-year plan for mental health. Lancet 367: 86.

12. Ryan-Harshman M, Aldoori W (2005) Health benefits of selected minerals. Can Fam Physician 51(5): 673-675.

13. Rayman MP (2000) The importance of selenium to human health. Lancet 356: 233-241.

14. Beard JL, Connor JR (2003) Iron status and neural functioning. Ann Rev Nutr 23: 41-58.

15. Coleman CI, Hebert JH, Reddy P (2003) The effects of Panax ginseng on quality of life. J Clin Pharm Ther 28(1): 5-15.

16. Das L, Bhaumik E, Raychaudhuri U, Chakraborty R (2011) Role of nutraceuticals in human health. J Food Sci Technol 49(2): 173-183.

17. Lutgendorf SK, Mullen-Houser E, Russell D, Degeest K, Jacobson G (2010) Preservation of immune function in cervical cancer patients during chemoradiation using a novel integrative approach. Brain Behav Immun 24: 1231-1240.

18. Ironson G, Field T, Scafidi F, Hashimoto M, Kumar M (1996) Massage therapy is associated with enhancement of the immune system's cytotoxic capacity. Int J Neurosci 84: 205-217.

19. Jain S, Hammerschlag R, Mills P, Cohen L, Krieger R (2015) Clinical studies of biofield therapies: Summary, methodological challenges, and recommendations. Glob Adv Health Med 4: 58-66.

20. Rubik B (2002) The biofield hypothesis: Its biophysical basis and role in medicine. J Altern Complement Med 8: 703-717.

21. Trivedi MK, Patil S, Shettigar H, Mondal SC, Jana S (2015) The potential impact of biofield treatment on human brain tumor cells: A time-lapse video microscopy. J Integr Oncol 4: 141

22. Trivedi MK, Patil S, Shettigar H, Gangwar M, Jana S (2015) In vitro evaluation of biofield treatment on cancer biomarkers involved in endometrial and prostate cancer cell lines. J Cancer Sci Ther 7: 253-257. 
23. Trivedi MK, Tallapragada RM (2008) A transcendental to changing metal powder characteristics. Met Powder Rep 63: 22-28, 31.

24. Trivedi MK, Nayak G, Patil S, Tallapragada RM, Latiyal O (2015) Studies of the atomic and crystalline characteristics of ceramic oxide nano powders after bio field treatment. Ind Eng Manage 4: 161

25. Trivedi MK, Branton A, Trivedi D, Nayak G, Charan S (2015) Phenotyping and 16S rDNA analysis after biofield treatment on Citrobacter braakii: A urinary pathogen. J Clin Med Genom 3: 129.

26. Trivedi MK, Patil S, Shettigar H, Mondal SC, Jana S (2015) An impact of biofield treatment: Antimycobacterial susceptibility potential using BACTEC 460/MGIT-TB System. Mycobact Dis 5: 189.

27. Trivedi MK, Branton A, Trivedi D, Nayak G, Mondal SC (2015) Morphological characterization, quality, yield and DNA fingerprinting of biofield energy treated alphonso mango (Mangifera indica L.). Journal of Food and Nutrition Sciences 3: 245-250.

28. Trivedi MK, Branton A, Trivedi D, Nayak G, Mondal SC (2015) Evaluation of biochemical marker - Glutathione and DNA fingerprinting of biofield energy treated Oryza sativa. American Journal of BioScience 3: 243-248.

29. Trivedi MK, Branton A, Trivedi D, Nayak G, Plikerd WD et al. (2017) A Systematic study of the biofield energy healing treatment on physicochemical, thermal, structural, and behavioral properties of magnesium gluconate. International Journal of Bioorganic Chemistry 2: 135-145.

30. Parulkar VR, Trivedi MK, Branton A, Trivedi D, Nayak G (2018) Improved metabolism of vitamin d3 in human osteoblasts cells after biofield energy healing treatment. American Journal of Laboratory Medicine 3 : 11-19.

31. Trivedi MK, Patil S, Shettigar H, Bairwa K, Jana S (2015) Phenotypic and biotypic characterization of Klebsiella oxytoca: An impact of biofield treatment. J Microb Biochem Technol 7: 203-206.

32. Nayak G, Altekar N (2015) Effect of biofield treatment on plant growth and adaptation. J Environ Health Sci 1: 1-9.

33. Branton A, Jana S (2017) The influence of energy of consciousness healing treatment on low bioavailable resveratrol in male Sprague Dawley rats. International Journal of Clinical and Developmental Anatomy 3: 9-15.

34. Branton A, Jana S (2017) The use of novel and unique biofield energy healing treatment for the improvement of poorly bioavailable compound, berberine in male Sprague Dawley rats. American Journal of Clinical and Experimental Medicine 5: 138-144.

35. Branton A, Jana S (2017) Effect of The biofield energy healing treatment on the pharmacokinetics of 25-hydroxyvitamin D3 [25(OH)D3] in rats after a single oral dose of vitamin D3. American Journal of Pharmacology and Phytotherapy 2: 11-18.

36. Parulkar VR, Trivedi MK, Branton A, Trivedi D, Nayak G et al. (2017) The use of consciousness energy healing based herbomineral formulation for skin anti-aging strategies. Journal of Food and Nutrition Sciences 5: 96-106.

37. Singh J, Trivedi MK, Branton A, Trivedi D, Nayak G et al. (2017) Consciousness energy healing treatment based herbomineral formulation: A safe and effective approach for skin health. American Journal of Pharmacology and Phytotherapy 2: 1-10.

38. Anagnos D, Trivedi K, Branton A, Trivedi D, Nayak G (2018) Influence of biofield treated vitamin $\mathrm{D}_{3}$ on proliferation, differentiation, and maturation of bone-related parameters in MG-63 cell-line. International Journal of Biomedical Engineering and Clinical Science 4(1): 6-14.

39. Lee AC, Trivedi K, Branton A, Trivedi D, Nayak G et al. (2018) The potential benefits of biofield energy treated vitamin $\mathrm{D}_{3}$ on bone mineralization in human bone osteosarcoma cells (MG-63). International Journal of Nutrition and Food Sciences 7: 30-38.

40. Stutheit ME, Trivedi K, Branton A, Trivedi D, Nayak G et al. (2018) Biofield energy treated vitamin $\mathrm{D}_{3}$ : Therapeutic implication on bone health using osteoblasts cells. American Journal of Life Sciences 6: 13-21.

41. Kučera O, Endlicher R, Roušar T, Lotková H, Garnol T, Drahota Z, Cervinková Z (2014) The effect of tert-butyl hydroperoxide-induced oxidative stress on lean and steatotic rat hepatocytes in vitro. Oxidative Medicine and Cellular Longevity 2014: 752506.

42. Liang F, Fang Y, Cao W, Zhang Z, Pan S, Xu X (2018) Attenuation of tertbutyl hydroperoxide (t-BHP)-induced oxidative damage in HepG2 Cells by tangeretin: Relevance of the Nrf2-ARE and MAPK signaling pathways. J Agric Food Chem 66(25): 6317-6325

43. Masrour Roudsari J, Mahjoub S (2012) Quantification and comparison of bone-specific alkaline phosphatase with two methods in normal and paget's specimens. Caspian J Intern Med 3(3): 478-483.

44. Kubo K, Yuki K, Ikebukuro T (2012) Changes in bone alkaline phosphatase and procollagen type-1 C-peptide after static and dynamic exercises. Res Q Exerc Sport 83(1): 49-54.

45. Liao YT, Chen CJ, Li WF, Hsu LI, Tsai LY, et al. (2012) Elevated lactate dehydrogenase activity and increased cardiovascular mortality in the arsenic-endemic areas of southwestern Taiwan. Toxicol Appl Pharmacol 262(3):232-7.

46. Hu EC, He JG, Liu ZH, Ni XH, Zheng YG, et al. (2015) High levels of serum lactate dehydrogenase correlate with the severity and mortality of idiopathic pulmonary arterial hypertension. Exp Ther Med 9(6): 21092113.

47. Kopel E, Kivity S, Morag-Koren N, Segev S, Sidi Y (2012) Relation of serum lactate dehydrogenase to coronary artery disease. Am J Cardiol 110(12): 1717-1722.

48. Limdi JK, Hyde GM (2003) Evaluation of abnormal liver function tests. Postgraduate Medical Journal 79: 307-312.

49. Kim WR, Flamm SL, Di Bisceglie AM, Henry C. Bodenheimer HC (2008) Serum activity of alanine aminotransferase (ALT) as an indicator of health and disease. 47(4): 1363-1370.

50. Liu Z, Que S, Xu J, Peng T (2014) Alanine aminotransferase-old biomarker and new concept: A review. Int J Med Sci 11(9): 925-935.

51. Siedlinski M, van Diemen CC, Postma DS, Vonk JM, Boezen HM (2009) Superoxide dismutases, lung function and bronchial responsiveness in a general population. Eur Respir J 33: 986-992.

52. Kinnula VL, Crapo JD (2003) Superoxide dismutases in the lung and human lung diseases. Am J Respir Crit Care Med 167(12): 1600-1619.

53. Peirson AR, Heuchert JW (2000) Correlations for serotonin levels and measures of mood in a nonclinical sample. Psychol Rep 87(3 Pt 1): $707-$ 716.

54.Williams E, Stewart-Knox B, Helander A, McConville C, Bradbury I, et al. (2006) Associations between whole-blood serotonin and subjective mood in healthy male volunteers. Biol Psychol 71(2): 171-174.

55. Lv J, Liu F (2017) The role of serotonin beyond the central nervous system during embryogenesis. Front Cell Neurosci 11: 1-7.

56. Bikle DD (2012) Vitamin D and bone. Curr Osteoporos Rep 10(2): 151159.

57. Yamamoto Y, Yoshizawa T, Fukuda T, Shirode-Fukuda Y, Yu T, et al. (2013) Vitamin D receptor in osteoblasts is a negative regulator of bone mass control. Endocrinology 154 (3): 1008-1020. 
(C) (P) This work is licensed under Creative

DOI: 10.32474/RRHOAJ.2019.03.000166

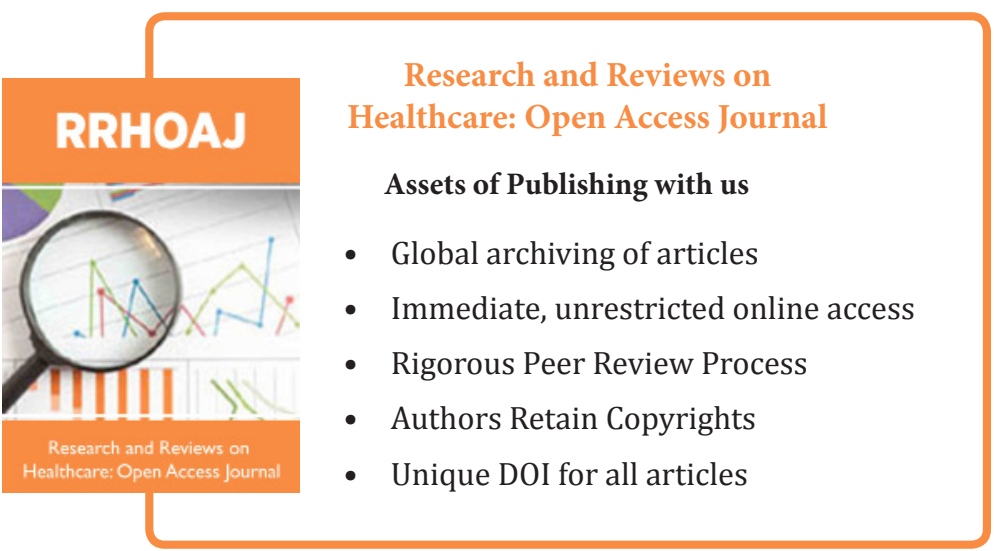

